\title{
Effects of petroleum exploitation on spatial pattern of agricultural production in Udu Local Government Area of Delta State, Nigeria
}

\author{
Jomata Lucky Igben and Johnson Omote Itabita \\ Department of Environmental Management and Toxicology, \\ Western Delta University, P.M.B.10 \\ Oghara, Delta State, Nigeria \\ Corresponding author \\ E-mail:joma_igben@yahoo.com \\ Tel.: +2348034037691
}

\begin{abstract}
Land and associated resources are crucial factors of agricultural production; hence, continuous petroleum exploitation activities cause an imbalance in the ecosystem and subsequently on agriculture. Against this background, this study examines the effects of petroleum exploitation on spatial pattern of agricultural production in Udu Local Government Area of Delta State, Nigeria. The primary source is a sample of 320 farmers chosen at random from two settlements selected from and outside Abura (OML 65) oil producing field. The questionnaire covered social and demographic characteristics of farmers and effects of petroleum exploitation on distance to farms, number, sizes of farms and output. Descriptive statistics and the pair-wise Student's t-test were used to analysed data collected for the study. The study reveals that petroleum exploitation resulted in increased distance to farms, reduced farm number and sizes and decreased agricultural output. There were significant differences in distance to farms $(\mathrm{t}=1.000, \mathrm{df}=9, \mathrm{p}<0.05)$, farm sizes $(\mathrm{t}=1.000, \mathrm{df}=9 ; \mathrm{p}<0.05)$ and agricultural output $(\mathrm{t}=0.578, \mathrm{df}=9, \mathrm{p}<0.05)$ of the two settlements selected from and outside oil producing field. Impact evaluation of petroleum exploitation activities is recommended for sustainable development of agriculture in the study area.
\end{abstract}

Keywords: Agriculture, agricultural production, impact evaluation, Delta State, petroleum exploitation

\section{Introduction}

Agriculture involves the modification of the natural land environment for the production of plants and animals, crops for subsistence and exchange (Igben\&Igun, 2017). All agricultural production activities can be categorized into human and physical aspects. The former constitutes the agricultural labour force or farmers while the latter is the physical or environmental correlates including soils, crops grown and animals reared. And since the physical aspects of agricultural production is carried out on the land; its spatial organization and pattern is strongly influenced by dynamics in land resources such as soil, forest, and water bodies induced by other human activities such as petroleum exploitation.

The effects of petroleum exploitation on agricultural production in the Niger Delta, the study area inclusive, have been the focus of several studies \{Inoni et al, 2006; Ahmadu \&Egbedion,
2013; Irhivben\&Omonona, 2013; Elum et al, 2016; Omamuyovwi\&Akpomuvie (2017)\}. For instance, Ashon-Jones et al (1998) asserted that oil exploitation damages the ecosystem, thus leading to deprivation and environmental health problems. Moreover, it is also fraught with accidental spillages which affect both the fauna and flora of the area resulting in direct negative effect on the overall productivity potential of the area. During oil exploitation, the landscape is disturbed considerably through path construction, trampling and vehicular movement. Thus, impacting negatively on agriculture (NEST, 1991: 87-88).

Asakatikpi and Oyediran (2000:186) stated that majority of the people in the Niger Delta are farmers and fishermen who rely solely on their immediate environment for survival; hence, anything that alters their environment threatens their very existence. In addition, 
Jomata Lucky Igben and Johnson Omote Itabita: Effects of petroleum exploitation on spatial pattern of agricultural production in Udu Local Government Area of Delta State, Nigeria

Aworawo (2000) observed that the dominant activities of the rural people of the Niger Delta are fishing and farming. To a lesser degree, they also engage in salt making and trading. Land is, therefore, crucial to the survival of the people of the region. The same is true of the rivers where the people fish.

Moreover, petroleum exploitation has led to adverse environmental impact on the soil, forest and water of the Niger Delta communities and reduced land for other economic activities (Akpofure et al, 2003). According to Omorodion (2004), the resourcefulness of the local farmers in the Niger Delta Region lies in their knowledge of the environment in terms of soil types, climate, and the suitable crop more likely to yield bountiful harvest. The farmers measure the soil types and fertility merely by rubbing the soil between the fingers. This practice enables them to identify the crops that grow on a particular soil and an estimate of the period of planting and harvesting to avoid significant loss. Fallow periods range from five to ten years in the past and the local people practised shifting cultivation due to abundance of land, fewer and homogenous population.

Furthermore, Aweto (2015) opined that oil spills and related disasters have resulted in loss of farmlands and forced migration to urban centres. Gas flaring has also robbed the people of valuable farmlands. Around each gas flare site, is an island of scorched and unproductive land which is the product of excessive evapotranspiration and thermal decomposition of soil organic matter, due to excessive high temperatures in the immediate vicinity of gas flare site.In a similar vein.Gbadegesin (1997) stated that petroleum exploitation, apart from leading to loss of farmlands, has led to extensive deforestation which has impacts on fallow periods, compound and degrade land use and reduce soil fertility. Similarly, Elum et al (2016) asserted that oil exploitation in the Niger
Delta Region has increased the rate of environmental degradation and has resulted in the death of fish and crops as well as loss of farm lands.

Ukoli (2001:15) stated, "pollution from oil exploitation induces loss of farmlands, economic crops, soil fertility and productive marine waters. All constitute massive and unquantifiable losses to farmers, fishermen and hunters, who depend on these sources for livelihood. This is in addition to the conditions of social disharmony, unemployment, squabbles and rivalry and competition for scarce farmlands or fishing grounds, general disaffection about government and sentiments in oilproducing communities". This development has led to a rise in social unrest, in the addition to violent protests by youths of the region.

Igben (2012) study of the impact of petroleum exploitation on labour force dynamics in Delta State revealed that petroleum exploitation had resulted in flooded farmlands, deforestation, reduced wildlife population, polluted water resources and a decline in economic activities particularly in agriculture. In addition, Magini (2006) study of the effects of oil exploitation in Emadadja, in Udu LGA of Delta State revealed that oil spillage in the area impacted negatively on water quality management and agriculture, which manifested in presence of heavy metals, thus leading to death of aquatic life, and sea birds, lobsters, fish and crabs. Similarly, Ugboma (2014) study of the effects of petroleum exploitation in Udu LGA showed that oil spillages have effects on soil fertility and adversely affected crop productivity in the area. In the same vein, Inoni et al (2006) study reveals that petroleum exploitation has led to environmental problems in the oil producing communities in Udu and Isoko North and Isoko South LGAs and has affected livelihood outcomes such as low 
Jomata Lucky Igben and Johnson Omote Itabita: Effects of petroleum exploitation on spatial pattern of agricultural production in Udu Local Government Area of Delta State, Nigeria

income, reduced food security, and severe health hazards among others.

In spite of the numerous studies on the effects of petroleum exploitation on agriculture in the Niger Delta Region, the study area inclusive, there has been no empirical study of its effect on spatial pattern and organization of agricultural production; hence this study aims to examine the resultant effects of continuous petroleum exploitation on spatial patterns of agricultural production in Udu Local Government Area of Delta State, Nigeria. Specifically, its objective is to determine the impact of petroleum exploitation on spatial pattern of agricultural production; namely, distance to farms, farm sizes, number of farms and output. The hypotheses tested in this study are:

(i) there is no significant difference in farm sizes between oil producing area and non-oil producing areas.

(ii) there is no significant difference in distance to farms between oil producing area and non-oil producing areas, and

(iii) there is no significant difference in agricultural output between oil producing area and non-oil producing areas.

This paper is divided into five sections. The first section has two components. The first part which has been examined deals with the background, aim and objective, and the hypotheses postulated for the study. The second part is on the conceptual framework in which the Pressure-State-Response model was considered. The second section of the study is on materials and methods in which the geography of the study area (Udu LGA) and the methodology adopted in the gathering and analysis of data for this study were examined. The results of the data analysed were presented and discussed in section three. These include the social and demographic characteristics of farmers, and effects of petroleum exploitation on spatial pattern of agricultural production. Section four is on conclusion and recommendations in light of the findings of the study. Lastly, the fifth section is the references.

\section{Conceptual framework}

This study is predicated on the PressureState-Response model proposed by Harrison and Pearce (2001). The model indicates that population pressure on the physical environment, which may be in form of a particular human activity such as exploitation of resources, cause impact. However, the level of pressure is determined by population, consumption and level of resource use and waste output these generate. The pressures lead to environmental degradation and depletion. The responses to this state of the environment are scarcity in land and hazards, which are in forms of feedbacks. Filters, which include science, monitoring, political and market systems set the overall conditions for the operation of other parameters.

The response of the society to these consequences of population pressure and resultant degradation of the physical environment are in forms of price shift, changes in spatial behaviour, culture, technology and resource management. Other responses are policy measures, regulations, taxation subsidy and so on. The model is schematically represented in Figure 1. 
Jomata Lucky Igben and Johnson Omote Itabita: Effects of petroleum exploitation on spatial pattern of agricultural production in Udu Local Government Area of Delta State, Nigeria

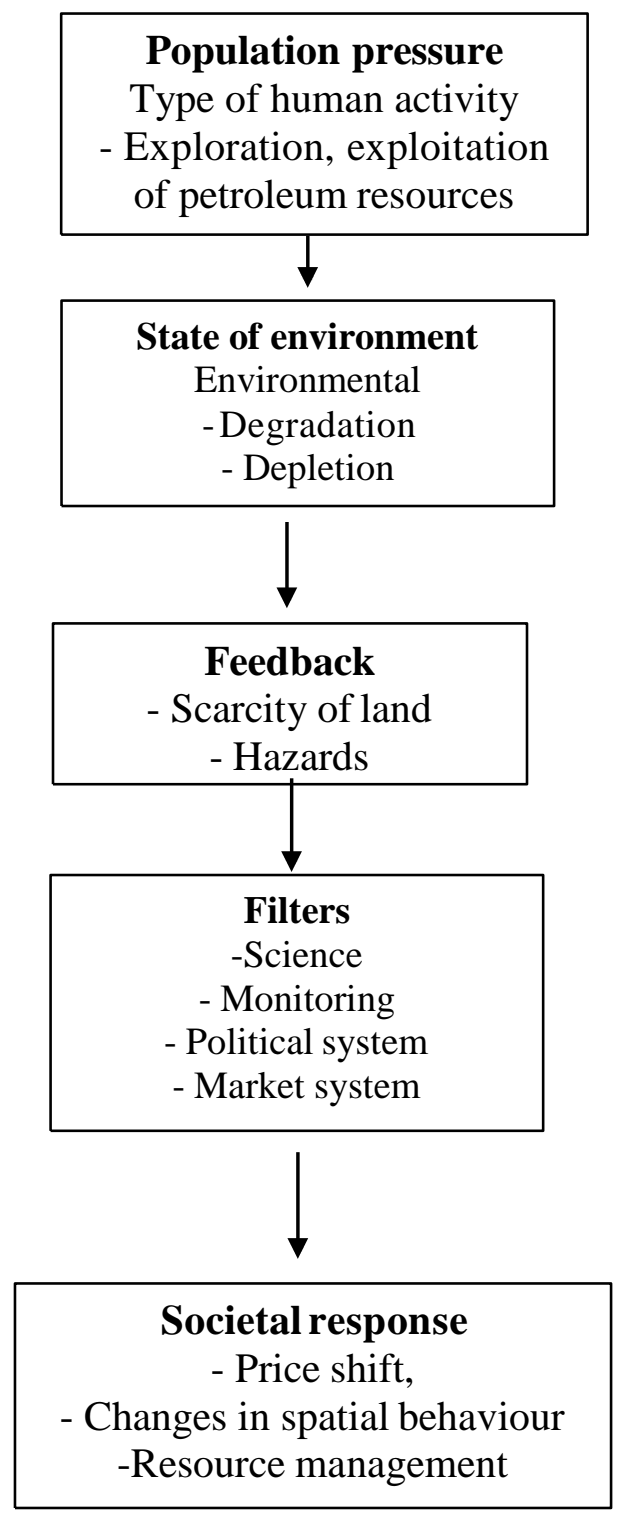

Figure 1: Pressure-State-Response Model

Adapted from Harrison and Pearce (2001).

In applying the model to this study, ongoing petroleum exploitation in the area has exerted pressure and impacted adversely on the environment, thus reducing the land available for agriculture. The response to this condition, as the model presupposes, would be in the form of changes in spatial behavior and resource management, and its consequences are within the realm of political and technological frame of the society.

\section{Materials andmethod Study area}

Udu is one of the twenty-five Local Government Areas (LGAs) of Delta State, Nigeria. It lies roughly between Latitudes 5045 " and 50 50" north and Longitudes 60 20 " and 6050 " east over an area of about 138 square kilometers. The LGA is bordered in the north by Uvwie LGA, by Ughelli South LGA in the South and East, while the Warri Southwest LGA is its western border as depicted in Figure 2. The study area has a vegetation of fresh water swamp, and a general land elevation 
Jomata Lucky Igben and Johnson Omote Itabita: Effects of petroleum exploitation on spatial pattern of agricultural production in Udu Local Government Area of Delta State, Nigeria

of less than 10 metres above sea level and lies in the fresh water swamp forest noted for floating grass, screw pine (Pandanascandelebrum) and raffia palm (Raphiahookeri) as the most common tree types. Thus, providing resources for a number of primary occupations (Lafua\&Igben, 2019).

The 2006 provisional national population census put the population of the Udu LGA at 142,480 persons, made up of 71,813 males and 70,667 females (NPC2006). The projected population of the study area in 2016 was 196,200 persons with population density of 1,432 persons per square kilometre (NBS, 2016). In 2019, using the national population growth rate of $2.7 \%$, the population of the area was estimated to be 218,136 persons. However, following the creation of the LGA in 1991 coupled with the rapid influx of people from the neighbouring Warri Township, the population of the area is estimated to be over 300,000 persons, with some of the settlements such as Aladja, Ovwian and Orhuwhorun undergoing rapid urbanization (Igben, 2019).

The major occupation of the people in the study area is farming. The main food crops grown are cassava (Manihotesculenta), yam (Dioscorespp), maize (Zea mays), vegetables and plantain (Musa spp). The cash crops are rubber (Heveabrasiliensis) and the oil palm
(Elaeisguineensis). The major types of farming practices in the area are bush fallowing and shifting cultivation. Crude implements, including cutlasses, hoes, and spades are used in preparing the soil for planting. Mechanization of farming is still at its infancy (Igben, 2012). Other occupations include fishing, lumbering, hunting, and tapping of rubber trees and raffia palm, gathering of fuel wood, collection of non-timber forest products like bamboo, palm nuts, screw pines, thatches, mushrooms, snails, fruits and herbs for medicinal purposes, trading and craftwork such as making of baskets, etc.

Udu LGA is home to the Abura (OML 65) oil producing field where petroleum exploration and exploitation activities have been on-going for over forty-one years. These activities include seismic surveys, land acquisitions, drilling, transportation (pipe laying), oil spillages, and waste dumping, and they affect the land in several ways such as contamination of streams and rivers, problems of oil spillages, forests destruction and biodiversity loss, effluent discharge and disposal, and the destruction of farm crops and farmlands (Igben 2012). The field covers eight settlements in the study area; namely, Emadadja, Ubogo, Ugbisi, Ekrota, Ukperhere, Okolor- Botor, Okolor- Burhie and Obubu. 
Jomata Lucky Igben and Johnson Omote Itabita: Effects of petroleum exploitation on spatial pattern of agricultural production in Udu Local Government Area of Delta State, Nigeria

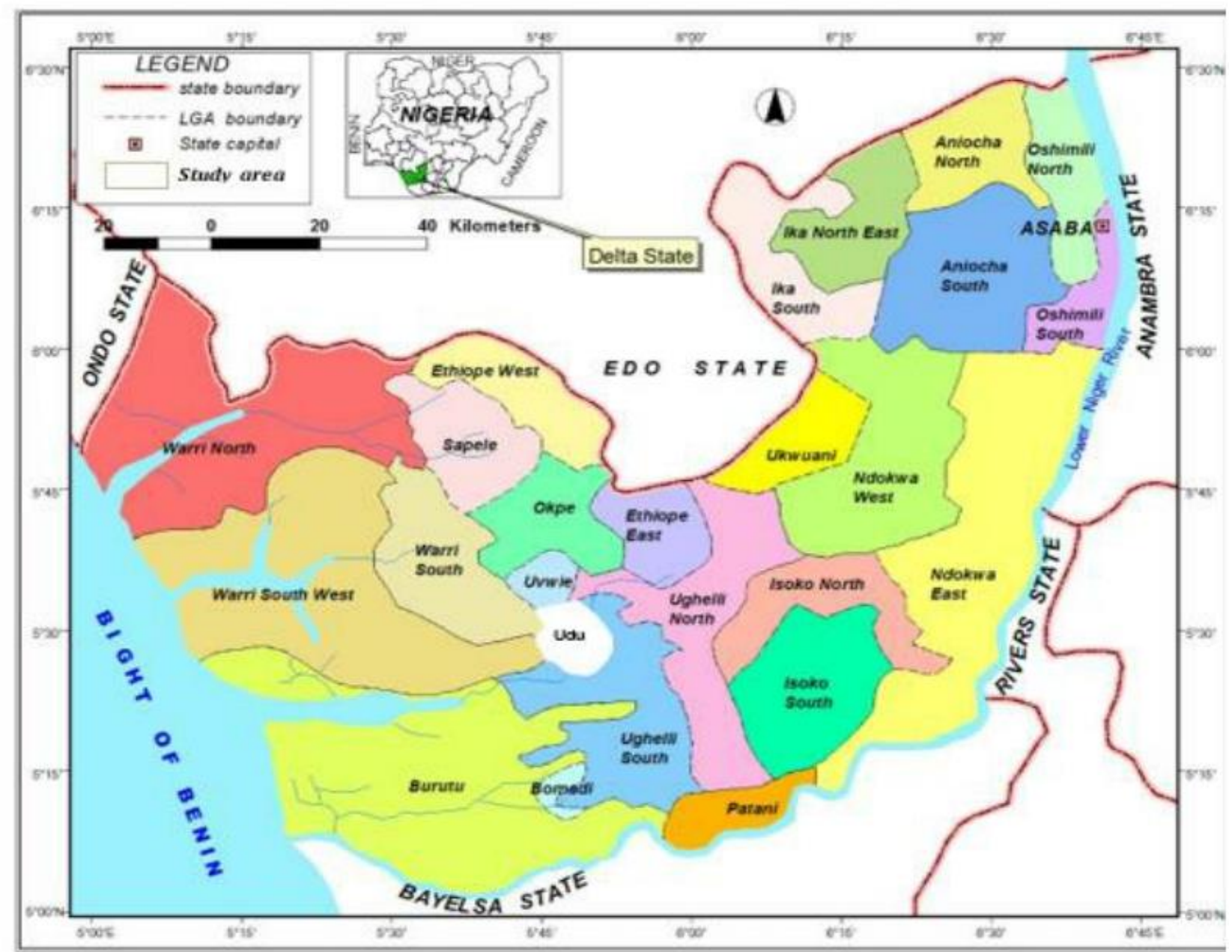

Figure 2: Delta State showing study area. Adapted from Igben (2012)

\section{Research design}

This study is a descriptive survey of the effect of petroleum exploitation on spatial pattern of agricultural production, which was measured by distance to farms, farm number, farm sizes and agricultural output. The choice of this research design is influenced by the nature of the research problem, personal experience of the researchers and the target population.

\section{Population and sample}

A total of 320 farmers were targeted in two settlements purposively chosen in the study area, one outside the Abura field, and another in the field. The selected settlements are Oleri and Ukperhere respectively. The two settlements are located on a homogenous physical environment. In each of the selected settlements, the total number of households engaged in farming was identified and estimated with the help of village head or his representative. A total of 3,610 farmers were identified in the two settlements, with at least 10 per cent targeted from each settlement. The systematic random sampling technique was employed for the selection of households in each selected settlement. This required a serial numbering of the households, after which a farmer was randomly picked. Subsequent ones were picked at a chosen interval until the total number of designated sample size in each settlement was achieved. To enable comparison to be made on the spatial pattern of agricultural production, a total of 160 farmers was targeted in each of the selected settlement. The questionnaire forms were distributed to the heads of the

Journal of Management and Social Science Research, Volume 1, Numbers 1/2, 2020 
Jomata Lucky Igben and Johnson Omote Itabita: Effects of petroleum exploitation on spatial pattern of agricultural production in Udu Local Government Area of Delta State, Nigeria

sampled households or their representatives.

The questionnaire used for the study was designed to cover all facets of the study. Each question was brief and carefully worded so that it was comprehended by the respondents in a way desired by the researcher. It comprises questions on location, socio-economic and demographic characteristics of farmers as well as information on distance to farms, number and sizes of farms, and output from agricultural production. At the end of the data collection exercise, which took place between 21st to 24th February, 2020, all the questionnaires were filled and returned to the four field assistants engaged for the field exercise.

Moreover, as output or yield of agricultural production varies in types and quantity, these variations were harmonized by converting to monetary terms. Thus, agricultural outputs were assessed using the 'going price' in the market for the products. This was done to enable comparison to be made between the selected settlements.

\section{Data analysis}

Data collected for the study were coded and compacted into manageable size. The frequencies of occurrence of events and percentages were worked out and presented in tables. The pair-wise Student's t-test was used to test the three hypotheses postulated in the study. Thus, the significant difference between the distance to farms; the significant difference between the sizes of farms and the significant difference between agricultural output on a category-bycategory basis, of the two selected settlements were tested.

\section{Results and discussion}

Social and demographic characteristics of farmers

Age and sex composition of farmers

Table 1 below presents the age and sex characteristics of the sampled farmers in the two settlements under study.

Table 1: Age and sex characteristics of sampled farmers

\begin{tabular}{|c|c|c|c|c|c|c|}
\hline \multirow{2}{*}{ Age group } & \multicolumn{2}{|l|}{ Oleri } & \multicolumn{4}{|c|}{ Ukperhere } \\
\hline & Males & Females & Males & Females & Total & Percentage \\
\hline Below 20 years & 3 & 0 & 1 & 1 & 5 & 1.5 \\
\hline $21-30$ & 10 & 2 & 17 & 4 & 33 & 10.3 \\
\hline $31-40$ & 13 & 7 & 11 & 6 & 37 & 11.6 \\
\hline $41-50$ & 22 & 5 & 17 & 12 & 56 & 17.5 \\
\hline $51-60$ & 21 & 16 & 24 & 12 & 73 & 22.8 \\
\hline Over 60 years & 23 & 38 & 28 & 27 & 116 & 36.3 \\
\hline Total & 92 & 68 & 98 & 62 & 320 & 100.0 \\
\hline
\end{tabular}

Source: Fieldwork, 2020

Table 1 shows that 245 farmers, representing 76.6 per cent of the sampled population of 320 farmers in the two settlements were above the age of 40 years. Out of this number, 116 farmers or 37.6 per cent were over 60 years, followed by those between 51 and 60 years old (73 farmers or 22.8\%) and those in the 41-50 years cohort with 56 farmers, representing 17.5 per cent. While 37 farmers or 11.6 per cent were between 31-40 years, 33 farmers or 10.3 per cent were between $21-30$ years. Only 5 farmers or 1.5 per cent were below 20 years old. Thus, indicating an ageing farming population which corroborate the finding of Igben (2012) study which revealed that the labour is depleting and ageing due to labour mobility from primary occupations to other sectors as a result of the adverse effects of petroleum

Journal of Management and Social Science Research, Volume 1, Numbers 1/2, 2020 
Jomata Lucky Igben and Johnson Omote Itabita: Effects of petroleum exploitation on spatial pattern of agricultural production in Udu Local Government Area of Delta State, Nigeria

exploitation in Delta State. In addition, majority of 182 farmers or $60 \%$ were males in contrast to 138 farmers or $40 \%$ who were females.

Also, majority of the 226 farmers or 70.6 per cent in the sampled settlements are Christians while 94 farmers 29.4 per cent practice African Traditional Religions (ATR). This finding is expected because Christianity is the dominant religion in the area (Imoroa, 2000). In addition, 204 farmers of 64.4 per cent of the sampled farmers had no form of formal education. While 66 farmers or 21.2 per cent and 44 farmers or 14.5 per cent had primary and secondary education respectively, 5 farmers representing 1.8 per cent of the sample had vocational training in motorcycle and motor repairs, welding, tailoring and hair dressing. Only one farmer or 0.1 per cent had tertiary education, as depicted in Figure 3.

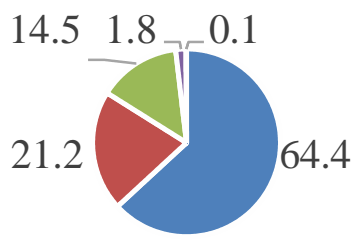

$$
\begin{aligned}
& \text { - No Formal Education }=\text { Primary Education } \quad \text { - Secondary Education } \\
& \text { - Vocational Education }=\text { Tertiary Education }
\end{aligned}
$$

\section{Figure 3: Educational background of farmers}

Source: Fieldwork, 2020

\section{Distance to farms}

Table 2 below shows the estimated area traverse to their various farms in the average distance the farmers in the study

two settlements under study.

\begin{tabular}{|c|c|c|c|c|c|}
\hline $\begin{array}{l}\text { Distance } \\
\text { Farms (km.) }\end{array}$ & to & $\begin{array}{l}\text { Frequency } \\
\text { Oleri }\end{array}$ & Ukperhere & Total & Percentage \\
\hline Less than 1.0 & & 12 & 3 & 15 & 4.7 \\
\hline $1.0-1.5$ & & 29 & 5 & 34 & 10.6 \\
\hline $1.6-2.0$ & & 36 & 9 & 45 & 14.0 \\
\hline $2.1-2.5$ & & 25 & 4 & 29 & 9.1 \\
\hline $2.6-3.0$ & & 21 & 7 & 28 & 8.8 \\
\hline $3.1-3.5$ & & 16 & 40 & 56 & 17.5 \\
\hline $3.6-4.0$ & & 8 & 33 & 41 & 12.8 \\
\hline $4.1-4.5$ & & 7 & 24 & 31 & 9.6 \\
\hline $4.6-5.0$ & & 4 & 19 & 23 & 7.2 \\
\hline Above 5.0 & & 2 & 16 & 18 & 5.6 \\
\hline Total & & 160 & 160 & 320 & 100.0 \\
\hline
\end{tabular}

Table 2: Estimated average distance to farms

Source: Fieldwork, 2020

Journal of Management and Social Science Research, Volume 1, Numbers 1/2, 2020 
Jomata Lucky Igben and Johnson Omote Itabita: Effects of petroleum exploitation on spatial pattern of agricultural production in Udu Local Government Area of Delta State, Nigeria

Table 2 reveals that 15 farmers representing $4.7 \%$ of the total sampled population of 320 farmers in the two settlements moved less than $1 \mathrm{~km}$ to their farms. Of this number, 12 farmers were from Oleri and three farmers were from Ukperhere. While 34 farmers or $10.6 \%$ moved between $1.0-1.5 \mathrm{~km}, 45$ farmers or $14.0 \%$ had farms located between 1.6 $-2.0 \mathrm{~km}$. Of this number, Oleri accounted for 29 farmers and 39 farmers respectively. However, there is a decrease in the number of farms with distance from $2.1-2.5 \mathrm{~km}$ and $2.6-3.0 \mathrm{~km}$ from 29 farmers or $9.1 \%$ to 28 farmers or $8.8 \%$ respectively. whileOleri decreased from 25 farmers to 21 farmers, Ukperhere increased from 4 farmers to 7 farmers. The distance between $3 \mathrm{~km}$ to $4 \mathrm{~km}$ accounted for $30.3 \%$ of the farms, with Oleri 16 farmers and 8 farmers and Ukperhere 40 farmers and 33 farmers for the $3.1-3.5 \mathrm{~km}$ and $3.6-4.0 \mathrm{~km}$ respectively.

Farmers whose farms are located between $4 \mathrm{~km}$ to $4.5 \mathrm{~km}$ and 4.6 to $5 \mathrm{~km}$ are Oleri, 7 farmers and 4 farmers and Ukperhere are 21 farmers and 23 farmers respectively. Only 18 farmers representing $5.6 \%$ had farms located over
$5 \mathrm{~km}$. Of these farmers, two were from Oleri and 18 from Ukperhere. Thus, farmers in area of petroleum exploitation move longer distance to farms located mostly over $3 \mathrm{~km}$. This finding buttressed the study by Igben (2012) which showed that changes in the distances to points of the economic activities changed significantly over the time as a result of petroleum exploitation in Delta State.

The pair-wise Student's t-test was used to test the statistically significant difference in the distance to farms between Oleri and Ukperhere. The result indicated that the ' $t$ ' value of 1.000 is significant at 0.05 level of confidence as shown in Table 5. Therefore, the difference in distance could be the result of petroleum exploitation, which has reduced land available for farming activities.

\section{Farm sizes}

Table 3 below shows the sizes of farms owned by farmers in the study area. The size of the farms recorded are the total sizes of all the farms owned by a farmer. This is because some farmers owned more than one farm in different locations.

Table 3: Average sizes of farms

\begin{tabular}{lccll}
\hline $\begin{array}{l}\text { Sizes of Farms } \\
\text { (Acres) }\end{array}$ & $\begin{array}{c}\text { Frequency } \\
\text { Oleri }\end{array}$ & Ukperhere & Total & Percentage \\
\hline Less than 1.0 & 21 & 10 & 31 & 9.7 \\
$1.0-1.5$ & 27 & 22 & 49 & 15.1 \\
$1.6-2.0$ & 22 & 21 & 43 & 13.4 \\
$2.1-2.5$ & 20 & 18 & 38 & 12.0 \\
$2.6-3.0$ & 17 & 17 & 34 & 10.6 \\
$3.1-3.5$ & 15 & 20 & 35 & 11.0 \\
$3.6-4.0$ & 19 & 12 & 31 & 9.7 \\
$4.1-4.5$ & 10 & 13 & 23 & 7.2 \\
$4.6-5.0$ & 6 & 11 & 17 & 5.3 \\
Above 5.0 & 3 & 16 & 19 & 6.0 \\
\hline Total & 160 & 160 & 320 & 100.0 \\
\hline
\end{tabular}

Source: Fieldwork, 2020 
Jomata Lucky Igben and Johnson Omote Itabita: Effects of petroleum exploitation on spatial pattern of agricultural production in Udu Local Government Area of Delta State, Nigeria

Table 3 reveals that a total of 31 farmers representing $9.7 \%$ in the two settlements owned farms smaller than one acre. Of this number, 21 farmers were from Oleri and 10 farmers were from Ukperhere. While 49 farmers or $15.1 \%$ had farms of between 1.0 - 1.5 acres, 43 farmers or $13.4 \%$ had farms of between $1.6-2.0$ acres. In these categories, Oleri accounted for 27 farmers and 22 farmers respectively while Ukperhere accounted for 22 farmers and 21 farmers respectively. However, for farm sizes of 2.12.5acres and 2.6 - 3.0acres, total farmers were 38 farmers or $12.0 \%$ and 34 farmers or $10.6 \%$ respectively. whileOleri accounted for 20 farmers and 17 farmers, Ukperhere accounted for 18 farmers and 17 farmers. Seventy-six (76) farmers representing $20.7 \%$ had farms which sizes are between 3 acres to 4 acres with Oleri 15 farmers and 19 farmers and Ukperhere 20 farmers and 12 farmers for the $3.1-3.5$ acres and $3.6-4.0$ acres respectively. Farmers with total farm sizes of between 4 acres to 4 . 5acres and 4.6 to 5acres are Oghior, 10 farmers and 6 farmers and Ukperhere are 13 farmers and 11 farmers respectively. Nineteen (19) farmers representing $6.0 \%$ had total farm sizes above 5acres. Of this, Oleri accounted for 3 farmers and Ukperhere had 16 farmers.

The pair-wise Student's t-test was used to test the statistically significant difference in farm sizes between Oleri and Ukperhere. The result indicated that the ' $\mathrm{t}$ ' value of 1.000 is significant at 0.05 level of confidence as shown in Table 5. Therefore, the difference in farm sizes could be the result of petroleum expnloitation, which has reduced land available for farming.

\section{Number of farms}

The study shows that the farmers in the area usually have more than one farm in different locations. Figure 4 below presents graphically the numbers of farms owned by the farmers in the two settlements under study.

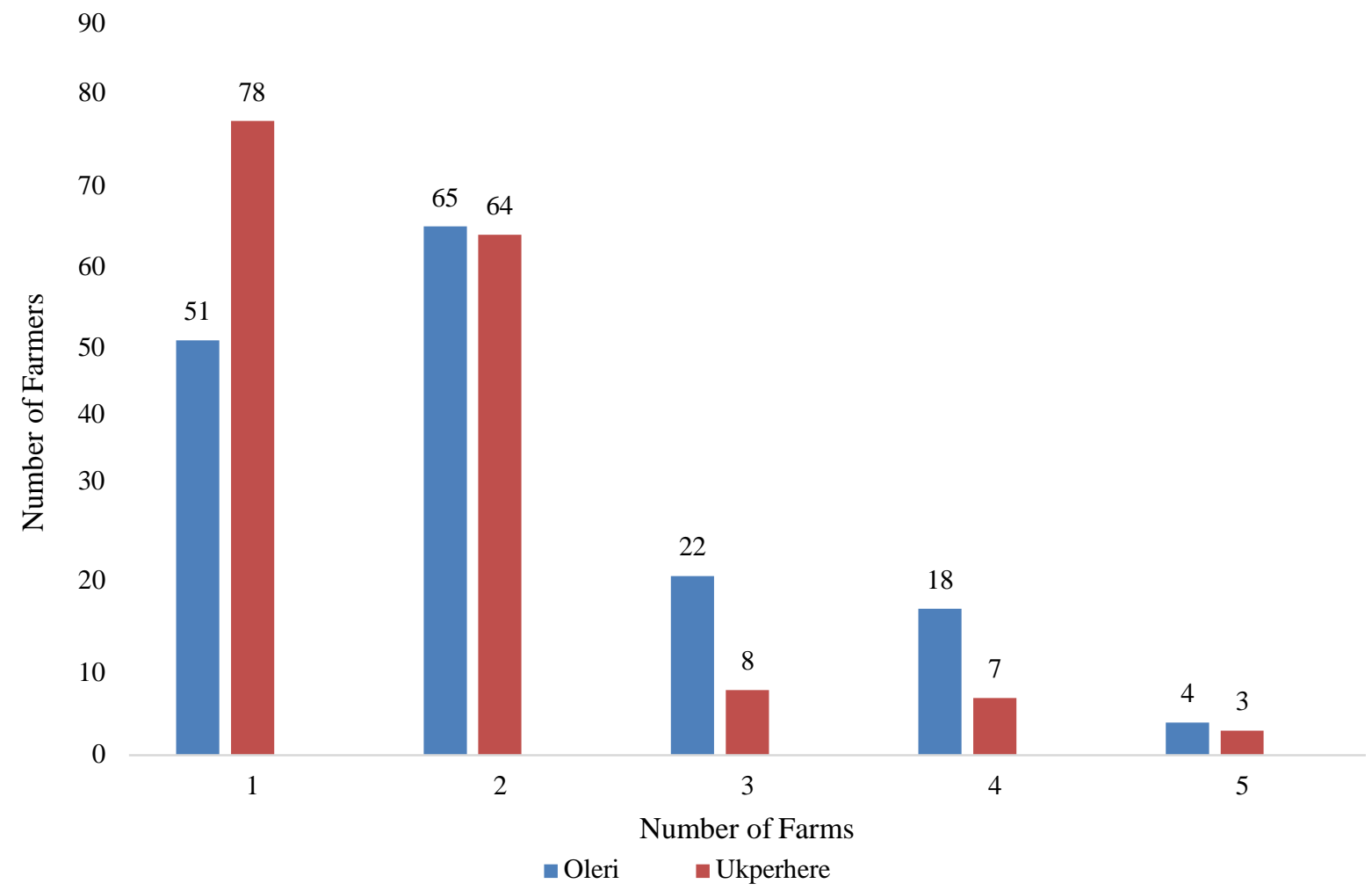

Figure 4: Number of Farms

Source: Fieldwork, 2020 
Jomata Lucky Igben and Johnson Omote Itabita: Effects of petroleum exploitation on spatial pattern of agricultural production in Udu Local Government Area of Delta State, Nigeria

Figure 4 (Bar chart) reveals that a total of 129 farmers representing $40.3 \%$ of the sampled population in the study area had only one farm. Of this number, 51 farmers $(15.9 \%)$ were from Oleri while 78 farmers $(24.4 \%)$ were from Ukperhere. A majority of 133 farmers or $41.6 \%$ owned two farms with 65 or $20.3 \%$ from Oleri and 68 farmers or $21.3 \%$ from Ukperhere. While a total of 30 farmers or $9.3 \%$ owned three farms (Oleri 22 farmers or $6.8 \%$, Ukperhere 8 farmers or 2.5\%), 22 farmers owned four farms (Oleri 18 farmers or $5.6 \%$, Ukperhere 4 farmers or $1.3 \%$ ). Only 6 farmers in the sampled population had five farms, 4 or $1.3 \%$ and 2 or $0.6 \%$ in Oleri and Ukperhere respectively. The average number of farms in Ukperhere on the oil field was 1.71 and that of Oleri, outside the oil field was 2.12. In sum, petroleum exploitation activities resulted to land degradation and consequently reduces the number the farms kept by farmers in the area.

\section{Output from farms}

Table 4 below shows the estimated annual total output from agricultural production in the selected settlements.

Table 4: Estimated annual income of farmers

\begin{tabular}{|c|c|c|c|}
\hline $\begin{array}{l}\text { Estimated Annual Income } \\
\text { (ㅌ0) }\end{array}$ & $\begin{array}{ll}\text { Frequency } \\
\text { Oleri }\end{array}$ & Ukperhere & Total \\
\hline Less than 500 & 10 & 30 & 40 \\
\hline $501-600$ & 11 & 27 & 38 \\
\hline $601-700$ & 7 & 24 & 31 \\
\hline $701-800$ & 24 & 28 & 52 \\
\hline $801-900$ & 30 & 21 & 51 \\
\hline $901-1000$ & 25 & 14 & 39 \\
\hline $1001-1100$ & 13 & 19 & 32 \\
\hline $1101-1200$ & 16 & 11 & 37 \\
\hline $1201-1300$ & 18 & 8 & 26 \\
\hline Above 1300 & 12 & 6 & 18 \\
\hline Total & 160 & 160 & 320 \\
\hline
\end{tabular}

Source: Fieldwork, 2020s

Table 4 reveals that 40 farmers of the total sampled population of 320 farmers in the two settlements received less than N500,000 per annum from farming. Of this number, 10 farmers were from Oleri while 30 farmers were from Ukperhere.

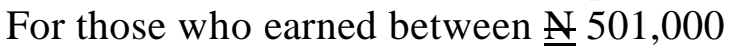
to $₫ 600,000,11$ farmers were from Oleri and 27 farmers from Ukperhere. While 7 farmers earned between $\underline{\mathbb{N}} 601,000$ and $\underline{\mathbb{N}}$ 700,000 in Oghior, 24 farmers received same in Ukperhere annually. However, 24 farmers and 28 farmers had estimated

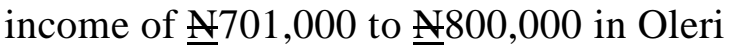
and Ukperhere respectively. For estimated

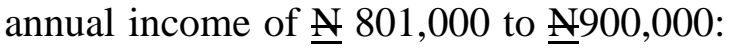
$\underline{N} 900,100$ to $\mathbb{N} 1000,000 ; \mathbb{N} 100,100$ and $\underline{\mathrm{N}} 1,101,000$ and $\underline{\mathrm{N}} 1,200,00 ; \underline{\mathrm{N}} 1,201,000$ and $\mathbb{1} 1,300,00$, Oleri had 13 farmers, 16 farmers, 18 farmers while Ukperhere had 19 farmers, 11 farmers, 8 farmers respectively. Only 18 farmers had income 
Jomata Lucky Igben and Johnson Omote Itabita: Effects of petroleum exploitation on spatial pattern of agricultural production in Udu Local Government Area of Delta State, Nigeria

of over $\mathbb{N} 1,300,000$ annually. Of these number, 12 farmers were from Oleri and 6 farmers from Ukperhere.

The pair-wise Student's t-test was used to test the statistically significant difference in the output from farms between Oleri and Ukperhere. The result indicated that the $\mathrm{t}$ value of 0.578 is significant at 0.05 level of confidence as shown in Table 5. The difference in output from farms could be the result of petroleum exploitation, which has degraded and reduced land available for farming. Following from this, the farmers in Ukperhere move longer distance to farms and keep more and smaller farms to increase output or income. This development in the study area is in line with the economic adaptation theories postulated by Ester Boserup (1965, 1981), Julian Simon (1982) and Kingsley Davis (1963). The thrust of these theories is that a decline in the resources base of the population as a result of environmental deterioration increase pressure on available resources. The population, in response to pressure would devise alternative ways of survival, which in this case, involves moving longer distances to farms and keeping multiple farms to improve income.

Table 5: Paired samples test

(Oleri) (Ukperhere)

\begin{tabular}{llllllll}
\hline Category & $\begin{array}{l}\text { Mean } \\
\text { Value }\end{array}$ & Std & $\begin{array}{l}\text { Mean } \\
\text { Value }\end{array}$ & Std & $\begin{array}{l}\text { paired } \\
\text { 't' test }\end{array}$ & Df & $\begin{array}{l}\text { Sig(2- } \\
\text { tailed) }\end{array}$ \\
\hline Distance & 16 & 11.430 & 16 & 12.256 & 1.000 & 9 & .000 \\
Farm sizes & 16 & 7.169 & 16 & 4.099 & 1.000 & 9 & .000 \\
Agric. & 16 & 17.130 & 16 & 8.208 & 0.578 & 9 & .000 \\
Output & & & & & & &
\end{tabular}

The ' $t$ ' values are significant at 0.05 confidence level.

\section{Conclusion and recommendation}

Land and associated resources are very crucial factors of agricultural production in the study area. Thus, petroleum exploitation activities such as seismic surveys, land acquisitions, drilling, transportation (pipe laying), oil spillages, and waste dumping have caused an imbalance in the ecosystem and have affected the spatial pattern of agricultural production in the study area. The effect on spatial patterns is reflected in the differences in farm sizes, distance to farms, number of farms and output from farming activities in areas of petroleum exploitation and areas outside the oil exploitation field.

Following from the above, the study recommends that an Impact Evaluation (IE) should be carried out to determine the impact of petroleum exploitation on the environment of the study area and on agriculture. Such evaluation should cover various aspects of the environment including physical, social, economic and aesthetic dimensions. Such IE of the petroleum exploitation activities should, therefore, include the following; a thorough understanding of all the petroleum exploitation activities and the environmental impact of these activities, a thorough understanding of the environment in which these activities take place, in terms of dynamics of human ecosystems, and a thorough understanding of the dynamic relationship between the exploitation activities and agriculture, with a view to promoting sustainable development of the study area.

\section{References}

Journal of Management and Social Science Research, Volume 1, Numbers 1/2, 2020 
Jomata Lucky Igben and Johnson Omote Itabita: Effects of petroleum exploitation on spatial pattern of agricultural production in Udu Local Government Area of Delta State, Nigeria

Ahmadu, J. \&Egbedion, J. (2013).Effects of oil spillage on Cassava production in the Niger Delta of Nigeria.American Journal of Experimental Agriculture, 3 (4):914-926

Akpofure, E.A.Efere, M.L \&Ayawei, P. (2003).A study of the oil spill in the Niger Delta. Retrieved Feb. 24, 2005 ,

from http//www.waado.org/Environmen /Petropollution

Asakitikpi, A.E. \&Oyediran, P.A. (2000).Oil extraction and the sociocultural impacts on the peoples of the Niger Delta.In OsuntokunAkinjide. Environmental problems of the Niger Delta. Lagos, Friedrich Ebert Foundation. Pg. 173-188.

Ashon-Jones, N., Arnott, S., \& Douglas, O. (1998).The Human ecosystem of the Niger Delta. Benin City, Environmental Rights Action

Aweto, A.O. (2015). Outline geography of Urhoboland. In Ekeh, P. (Ed).Studies in Urhobo culture.Bufallo: Urhobo Historical Society, pp 683-698

Aworawo, D. (2000). The impact of environment degradation in the rural economy of the Niger Delta. In OsuntokunAkinjide (ed). Environmental problem of the Niger Delta. Lagos: Friedrich Ebert Foundation. $150-163$.

Boserup, E.(1965). Conditions for agricultural growth. London, George Allen and Unwin.

Boserup, E.(1981). Population and technology.Oxford, Basil Blackwell.

Davis, K. (1963). The theory of change and response in modern demographic history.Population Index Activities, Vol. 29 No.4: 345366.

Elum, Z.A., Mopipi, K. \& Henri-Okoha, A. (2016).Oil exploitation and its socio-economic effects on the
Niger Delta of

Nigeria.Environmental Science and Pollution Research, 23, 1288012889

Gbadegesin, A. S. (1997). The impact of oil exploration and production activities on the environment: implication for peasant agriculture. Journal of Oil and Environment: Seminar Paper on the Oil and the Environment Organized by Friedrich Ebert Foundation, Port Harcourt

Harrison, P. \& Pearce, F. (2001).AAAS atlas of population and environment.Beckley, University of California Press.

Igben, J. L. (2012). Petroleum exploitation and labour force dynamics: A spatiotemporal analysis. Saarbrucken, Germany: LAP Lambert Academic Publishing. 252 pages.

Igben, J. L. \&Igun, E. (2017).Socioeconomic and demographic profile of the agricultural labour force in Delta State, Niger Delta Region of Nigeria.Journal of Environmental Issues and Agriculture in Developing Countries, 9(1): 42-50

Igben. J. L. (2019). Analysis of poverty and environmental degradation in Udu Local Government Area of Delta State, Nigeria.Confluence Journal of Environmental Studies, 13(1):143-152.

Imoara, N. O. (2000). Delta State. Nigeria. In Mamman, J. O. Oyebanji and S.W. Petters. (Eds.) A people united, a future assured. Vol. 2, A. B. Calabar, Gabumo Publishing.

Inoni, O., Omotor, D. \&Adun, F.A. (2016).The effects of oil spillage on crop yield and farm income in Delta State, Nigeria.Journal of Central European Agriculture, $7(1): 41-48$

Irhivben, B.O. \&Omonona, B. T. (2013).Implications of oil exploitation on agricultural 
Jomata Lucky Igben and Johnson Omote Itabita: Effects of petroleum exploitation on spatial pattern of agricultural production in Udu Local Government Area of Delta State, Nigeria

development in Delta State, Nigeria.International Journal of Humanities and Social Sciences, 2(4):59-63

Lafua, I. W. \&Igben, J. L. (2019).Udu Clan and its people.In Delekpe, E.B.O. (Ed.) AHistory of the Udu People and Urhobo Nation of Nigeria.Benin City; Mindex Publishing Company Limited. pp. 31-39.

Magini, E. J. (2006). Effects of oil spillage on water quality management in Emadadja in Udu Local Government Area, Delta State, Nigeria.An M.Sc. Research Study of Department of Environmental Science, Nnamdi Azikiwe University, Awka.

Nigerian Bureau of Statistics (NBS) (2016).Nigerian Bureau of Statistics general household Survey.Wave 3 (post Planting) 2015-2016.Third Round.Http://www.nigerian.gov.ngpanel. Retrieved on January 23, 2020

National Population Commission (NPC) (2006). Provisional population census report.Vanguard, Wednesday 10 January 2007.

Nigerian Environment Study/Action Team (NEST) (1991). Nigerian Threatened environment; Anational profile.A NEST Publication.

Omamuyovwi, A. I. \&Akpomuvie, M. (2017)).The impact of oil exploitation on the socio-economic life of OrogunCommmunity, an oil producing Community in Delta State, Nigeria.American Journal of Environmental and Resource Economics, 2(2):73-79.

Omorodion, F.I. (2004). The impact of petroleum refinery on the economic livelihood of women in the Niger Delta Region of Nigeria JENDA: A journal culture and African Women Studies, Issue 6. Retrieved Feb. 24, 2006, from www.liav.ni/ezines/ web/JENda/2005/No6/jendajournal /omorodion.html

Simon, J.L. (1982). Answer to Malthus: Julian Simon interview by William Beckley. Population and Development Review, Vol. 8, No.

Ugboma, P. P. (2014). Effects of oil spillage in Udu Local Government Area in Delta State International Journal of Science and Technology, $3(3): 47-56$

Ukoli, M.K. (2001). Environmental factors in management of the oil and gas in Nigeria. Retrieved July 28, 2006 from http//www.cenbank.org/out/annual/A CZRU/2001: 1-28. 